九州大学学術情報リポジトリ

Kyushu University Institutional Repository

Contributions of Jellyfish Fertilizer to

Survival and Growth of Seedlings Planted in a Recently Burned Forest, Republic of Korea

Seo, Jung-Il

Department of Forest Resources, College of Industrial Sciences, Kongju National University

Kim, Yong-Rae

Department of Forest Resources, College of Forest and Environmental Sciences, Kangwon National University

Otsuka, Kyoichi

Kasuya Research Forest, Kyushu University

Kim, Suk-Woo

Department of Forest Resources, College of Forest and Environmental Sciences, Kangwon National University

他

https://doi.org/10.5109/1434410

出版情報：九州大学大学院農学研究院紀要. 59 (1)，pp. 181-189，2014-02-28. Faculty of Agriculture, Kyushu University

バージョン :

権利関係 : 


\title{
Contributions of Jellyfish Fertilizer to Survival and Growth of Seedlings Planted in a Recently Burned Forest, Republic of Korea
}

\author{
Jung-II SEO ${ }^{1}$, Yong-Rae KIM ${ }^{2}$, Kyoichi OTSUKI ${ }^{3}$, Suk-Woo KIM ${ }^{2}$, Kyu-Jin YEOM ${ }^{4}$, \\ Jae-Seon $\mathrm{YI}^{2}$, Young-Sang AHN ${ }^{5}$, Tsugio EZAKI ${ }^{6}$ and Kun-Woo CHUN ${ }^{2 *}$
}

\author{
Laboratory of Ecohydrology, Division of Forest Environmental Sciences, \\ Department of Agro-Environmental Sciences, Faculty of Agriculture, \\ Kyushu University, Sasaguri, Fukuoka 811-2415, Japan \\ (Received October 31, 2013 and accepted November 11, 2013)
}

\begin{abstract}
In April 2012, a forest fire burned a large proportion of the understory and overstory vegetation on Mount Jubong, which is located in Hoengseonggun, Gangwondo in the Republic of Korea. In this forest, we examined the contributions of jellyfish fertilizer on survival and growth of Pinus thunbergii and Quercus palustris seedlings. The results showed that jellyfish fertilizer contributed high concentrations of the available moisture and nutrients to soil conditions. Jellyfish fertilizer contains high concentration of organic matter, which plays an important role for improving the physical structure of the soil. This is likely to increase the soil moisture and supply nutrients, which could promote survival and growth of seedlings. However, the effect of jellyfish fertilizer on survival of $Q$. palustris seedlings varied with its application rate whereas it of $P$. thunbergii seedlings increased with application rate of jellyfish fertilizer. This should be because that excessive salt concentration, which can be caused by high application of jellyfish fertilizer, affect adversely the growing plants and/or root distribution. Under the considering survival rates of both seedlings, the results showed that the optimum application rates of jellyfish fertilizer for enhancement of seedling growths were $50 \mathrm{~g} /$ tree for $P$. thunbergii seedlings and $30 \mathrm{~g} /$ tree for $Q$. palustris seedlings, respectively. This reflects that the jellyfish fertilizer promotes soil amendment, and has a positive contributor to the growths of both shoot and root parts, which is obviously required to secure competitiveness in an early growth stage. Although this study was spatially and temporarily limited, the findings are likely to provide important information regarding the establishment of forest restoration strategies in the burned and degraded areas where the possibilities of human and property damages are high.
\end{abstract}

Key words: jellyfish fertilizer, post-fire, rehabilitation treatment, seedling growth, seedling quality index

\section{INTRODUCTION}

Fire is a natural and significant part of the disturbance regime affecting hydrology and geomorphology in forested landscapes (Hamilton and Rowe, 1949; Swanson, 1981). Although forest fires are highly variable depending on location, climate, topography, soil type and fire severity and extent, they produce a reduction in the coverage of the litter layer on the forest floor and of the understory and/or overstory vegetation, causing quantitative and qualitative changes in the hydrological response and subsequent surface soil erosion of burned areas (DeBano, 1981; McNabb and Swanson, 1990; Meyer and Wells, 1997; Shakesby and Doerr, 2006). These

${ }^{1}$ Department of Forest Resources, College of Industrial Sciences, Kongju National University, 54 Deahakro, Yesaneup, Yesangun, Chungcheongnamdo 340-702, Republic of Korea

Department of Forest Resources, College of Forest and Environmental Sciences, Kangwon National University, 1 Kangwondaehakgil, Chuncheon, Gangwondo 200-701, Republic of Korea

Kasuya Research Forest, Kyushu University, Sasaguri, Fukuoka 811-2415, Japan

Korea Forest Conservation Associations, 114-1 Taebongro, Seochogu, Seoul 137-901, Republic of Korea

Division of Forest Resources, College of Agriculture and Life Sciences, Chonnam National University, Gwangju 500-757, Republic of Korea

${ }^{6}$ Faculty of Agriculture, Ehime University, 3-5-7 Tarumi, Matsuyama, Ehime 790-8566, Japan

* Corresponding author (E-mail: kwchun@kangwon.ac.kr) changes in the post-fire hydrologic regime and surface soil erosion are further affected by other environmental factors, such as rainfall amount and intensity, slope, aspect, and vegetation type and recovery rate (Marques and Mora 1992; Gimeno-García et al., 2007; Lanini et al., 2009) and ultimately influence the delivery of sediment to stream channels (Cannon et al., 2001; Benda et al., 2003). Therefore, increasing overland flow and surface soil erosion in burned areas can lead to the risk of flooding and sedimentation, which impairs aquatic habitats of stream-dwelling organisms and threatens human life, property, and natural resources both within and outside of the burned area (Robichaud et al., 2000; Graham, 2003).

Numerous studies (e.g., Meyer and Wells, 1997; Cannon et al., 2001; Martin and Moody, 2001; Lee et al., 2004) reported that the majority of surface soil erosion in burned areas occured in the first two years following the forest fire. However, in recent years, several studies (e.g., Kim et al., 2008; Seo et al., 2010) found that severely burned areas with steep slopes required at least three years to achieve surface soil stability by the natural recovery of the native vegetation. Therefore, in the burned and degraded areas where the possibilities of human and property damages are high, prompt field rehabilitations are strongly required to stabilize the surface soil within a short time.

As one of the emergent rehabilitation treatments, tree planting is commonly applied for early vegetation 
recovery and subsequent surface stability in the Republic of Korea (Chun et al., 2003; Seo, 2004). Under the ground, trees reinforce soil layers and form buttresses against soil movement (Abe and Ziemer, 1991), and influence soil moisture level and thus reduce landslide risks (Watson et al., 1999). Above the ground, trees lead to rainfall interception and reduced overland flow, thereby reducing surface soil erosion (Swanson, 1981; Gimeno-Garcia et al., 2007). At the time of tree planting, fertilizer is often applied to facilitate optimal growth of seedlings and to maximize subsequent reforestation success (Austin and Strand, 1960; Carlson and Preisig, 1981; Rose and Ketchum, 2003).

Recently, with a high consideration on envirommental protection, organic fertilizers gain increasing global attention. Jellyfish, which has increased dramatically worldwide and thereby has caused various damages in coastal areas (Ishii and Tanaka, 2001; Kang and Park, 2003; Uye and Shimauchi, 2005), can be used as a source of organic fertilizer for enhancing tree growth and improving soil properties in terms of physical and chemical properties. Fukushi et al. (2004) conducted the experiments for the potential use of jellyfish as a fertilizer for the vegetable field. They reported that jellyfish had high concentrations of five principle components of fertilizer (i.e., nitrogen, phosphorus, potassium, magnesium, and calcium) and thus had a positive effect on the growth rates of vegetables. Similarly, Ezaki et al. (2011) examined the possibility of jellyfish fertilizer application to tree survival and growth for erosion control works on the degraded mountain hillslopes. Despite these studies suggested that jellyfish have a high possibility as an organic fertilizer, no study documented the usefulness of jellyfish fertilizer for early and successful restoration in burned forest areas.

As a case study to examine the contributions of jellyfish fertilizer on survival and growth of seedlings planted in a recently burned forest, we first planted seedlings of Pinus thunbergii and Quercus palustris on a recently burned hillslope. At this time, we applied jellyfish fertilizer of $0,10,30$ and $50 \mathrm{~g} /$ tree at $10 \mathrm{~cm}$ in depth around the roots of seedlings. Then, we investigated changes in soil property and subsequent survival and growth rates of seedlings, which were regulated by different application rates of jellyfish fertilizer. Based on the results, we finally suggested the best application rate of jellyfish fertilizer for early restoration in burned forest areas.

\section{STUDY SITE}

Fieldwork was conducted on a hillslope on Mount Jubong (713.3 m), which is located in Hoengseonggun, Gangwondo in the Republic of Korea (Fig. 1). The study hillslope is primarily underlain by igneous rock which was formed through the cooling and solidification of magma or lava. In addition, the surface of the study hillslope is mainly covered by poorly graded sands, based on the Unified Soil Classification System, which is widely used in Southeast Asia.

Initially, the study hillslope was primarily covered with evergreen conifers (e.g., $P$. densiflora) with $10-26 \mathrm{~cm}$ in diameter at breast height and 5-10 $\mathrm{m}$ in height and broad-leaved tree (e.g., Q. variabilis, Q. mongolica) with $8-16 \mathrm{~cm}$ in diameter at breast height and 5-10 $\mathrm{m}$ in height. However, in April 2012, a large proportion of the understory and overstory vegetation of the hillslope were consumed by a fire. Upon considering the fire severity classification proposed by Agee (1993), this fire can be classified into mixed-severity fire regime.

The study area has a temperate climate with four seasons. According to meteorological data for the past ten years (2003-2012), which were monitored at the Hoengseong dam reservoir management office closest to the study site, the mean annual temperature is approximately $11.9^{\circ} \mathrm{C}$ and the mean annual precipitation ranges from 1,142 $\mathrm{mm}$ to 2,026 mm. Most precipitation occurs as localized torrential downpours caused by typhoons between July and September and as frontal rainstorms in the summer.

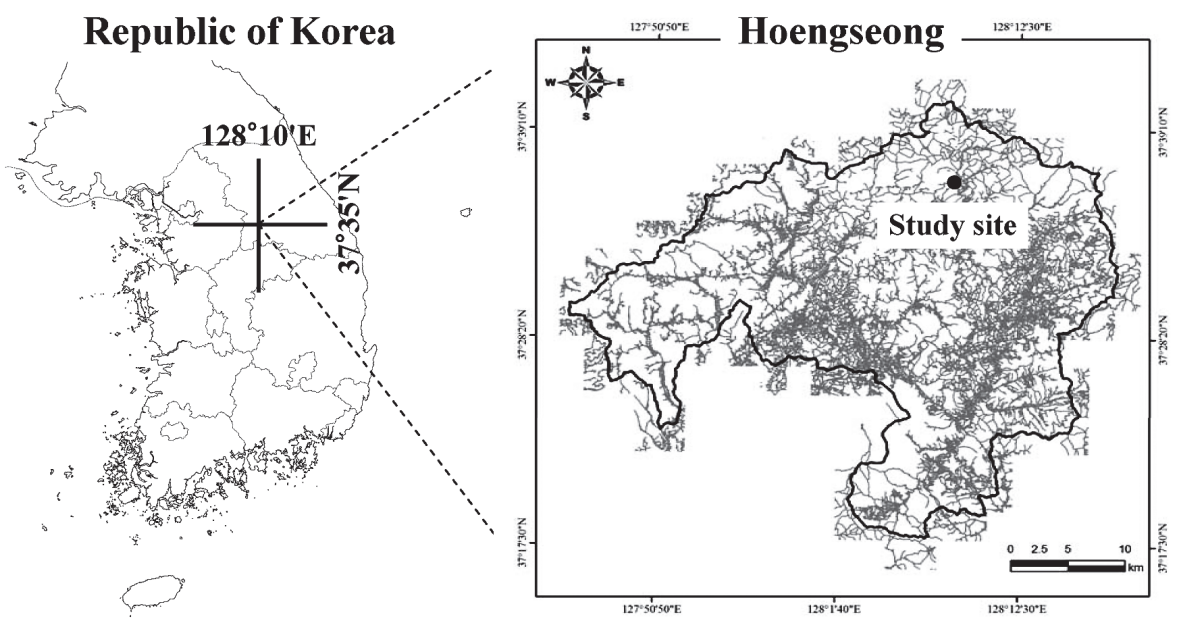

Fig. 1. Location of the study site. 
Table 1. Experimental design of the field experiment

\begin{tabular}{cccccc}
\hline $\begin{array}{c}\text { Planted seedling } \\
\text { Species }\end{array}$ & $\begin{array}{c}0 \mathrm{~g} / \text { tree } \\
\text { (Untreated control) }\end{array}$ & $10 \mathrm{~g} /$ tree & $30 \mathrm{~g} /$ tree & $50 \mathrm{~g} /$ tree & Total \\
\hline $\begin{array}{c}\text { Pinus thunbergii } \\
\text { Quercus palustris }\end{array}$ & 12 & 12 & 12 & 12 & 48 \\
\hline
\end{tabular}

\section{METHODS}

\section{Hillslope treatments}

At the beginning of June in 2012, the burned trees on the study hillslope were manually cut and skidded, and then two plots with $4 \mathrm{~m}$ wide and $12 \mathrm{~m}$ long were established. To normalize the potential effects of rainfall events across the plots, the plots were established at the distance of approximately $20 \mathrm{~m}$ on the slope with steep gradient of approximately $35^{\circ}$. We planted twoyear-old seedlings of $P$. thunbergii in one plot and $Q$. palustris in the other plot. Here, we planted the seedlings of approximately $1.0 \mathrm{~m}$ apart in vertical and horizontal rows at the density of 48 trees per plot. Each plot was vertically subdivided into four subplots based on the jellyfish fertilizer treatments: 0 (untreated control), 10, 30 and $50 \mathrm{~g} /$ tree (Table 1). The methods of jellyfish fertilizer application and seedling planting are as described in the following: 1) excavated the planting holes with $30 \mathrm{~cm}$ in diameter and $30 \mathrm{~cm}$ in depth;2) put the excavated sediment in the holes up to $10 \mathrm{~cm}$ in depth after provisional standing of seedlings; 3) dredged evenly jellyfish fertilizer around the roots of the seedlings but without any touch the roots; 4) finally covered the dredged jellyfish fertilizer and filled the holes with the excavated sediment.

\section{Evaluation of seedling survival and growth}

To examine the effect of jellyfish fertilizer on the survival and growth of seedlings, we counted the number of the survived seedlings, and measured the height from the soil surface to the top and the root-collar diameter at $5.0 \mathrm{~cm}$ above the soil surface at the beginning (June) and the end (September) of field experiment.

At the end of field experiment, we gently removed three seedlings from each plot and dried them for approximately 48 hours in the oven with $70^{\circ} \mathrm{C}$ after thorough cleaning. Then, the oven-dried seedlings were separated into shoot and root parts, and their dryweights were recorded. Using these data, we calculated seedling quality index (SQI) which is commonly used to evaluate the healthiness of seedling (Deans et al., 1989; Bayala et al., 2009). The SQI was defined as:

$$
\mathrm{SQI}=\mathrm{SD} /(S \cdot R+H \cdot D)
$$

where SD is total dry-weight of each seedling (g), and $S$ and $R$ are the dry-weights (g) of seedling shoot and root, respectively. $H$ and $D$ are the height $(\mathrm{cm})$ and root-collar diameter (mm) of seedling, which were measured previously.

\section{Evaluation of on-site soil conditions}

During August-September in 2012, soil moisture was measured three times at three different places within each subplot. We used soil moisture meter (Model PMS-714): the soil moisture probe was placed into $10 \mathrm{~cm}$ in depth of the soil and then the moisture data were recorded automatically.

At the removal stage, soil samples were collected at a depth of $10-30 \mathrm{~cm}$ in the center of each subplot to examine the effects of soil chemical property on the seedling survival and growth. The soil samples were air-dried and then sieved with a $2 \mathrm{~mm}$ sieve (US Standard No. 10). Using the sieved sample, hydrogen ion concentration $(\mathrm{pH})$, electrical conductivity (EC), organic matter content $(\mathrm{OM})$, and $\mathrm{NO}_{3}^{-}, \mathrm{P}_{2} \mathrm{O}_{5}, \mathrm{~K}_{2} \mathrm{O}, \mathrm{Cl}^{-}$ and $\mathrm{Na}^{+}$contents were analyzed.

\section{Statistical analysis}

One-way analysis of variance (ANOVA) was used to evaluate significant differences as a function of application rates of jellyfish fertilizer in the heights, root-collar diameters and SQI. Nested ANOVA was also used to evaluate significant differences as a function of application rates of jellyfish fertilizer in the soil moisture. When the effects of application rates of jellyfish fertilizer were significantly different on one-way and nested ANOVA, Tukey-HSD multiple comparisons were performed. The normality of distributions was tested using the Kolmogorov-Smirnov test. $P<0.05$ was considered to indicate statistical significance for all tests. The statistical analysis was carried out with the statistical software package SPSS (20).

\section{RESULTS}

\section{Soil moisture}

The results showed that mean soil moisture contents of both plots increased significantly with increasing application rate of jellyfish fertilizer (Fig. 2). Specially, the mean soil moistures in the subplot treated with jellyfish fertilizer of $50 \mathrm{~g} /$ tree were approximately two to three times greater than those in the untreated control subplot, respectively.

\section{Soil chemical property}

All soil chemical properties analyzed in this study were clearly regulated by the application rate of jellyfish fertilizer (Table 2). With increasing application rate of jellyfish fertilizer, the $\mathrm{pH}$ decreased from 5.9 ( $0 \mathrm{~g} /$ tree $)$ to 5.4 ( $50 \mathrm{~g} /$ tree) but the EC increased from $0.05 \mathrm{dS} / \mathrm{m}$ ( $0 \mathrm{~g} /$ tree) to $0.30 \mathrm{dS} / \mathrm{m}$ ( $50 \mathrm{~g} /$ tree $)$. In addition, the appli- 
Table 2. Change in soil chemical properties in relation to the application rates of jellyfish fertilizer

\begin{tabular}{ccccccccc}
\hline $\begin{array}{c}\text { Application rate of } \\
\text { jellyfish fertilizer } \\
(\mathrm{g} / \mathrm{tree})\end{array}$ & $\mathrm{pH}$ & $\mathrm{EC}$ & $\begin{array}{c}\mathrm{OM} \\
(\%)\end{array}$ & $\begin{array}{c}\mathrm{NO}_{3}^{-} \\
(\mathrm{mg} / 100 \mathrm{~g})\end{array}$ & $\begin{array}{c}\mathrm{P}_{2} \mathrm{O}_{5} \\
(\mathrm{mg} / 100 \mathrm{~g})\end{array}$ & $\begin{array}{c}\mathrm{K}_{2} \mathrm{O} \\
(\mathrm{mg} / 100 \mathrm{~g})\end{array}$ & $\begin{array}{c}\mathrm{Cl}^{-} \\
(\mathrm{mg} / 100 \mathrm{~g})\end{array}$ & $\begin{array}{c}\mathrm{Na}^{+} \\
(\mathrm{mg} / 100 \mathrm{~g})\end{array}$ \\
\hline $\begin{array}{c}\text { (Untreated control) } \\
0\end{array}$ & 5.9 & 0.05 & 4.9 & 3.0 & 0.3 & 6.2 & 0.05 & 0.5 \\
10 & 5.8 & 0.1 & 5.6 & 4.2 & 0.4 & 6.6 & 0.1 & 0.6 \\
30 & 5.6 & 0.2 & 5.7 & 5.4 & 0.5 & 7.0 & 0.2 & 0.7 \\
50 & 5.4 & 0.3 & 6.6 & 6.1 & 0.6 & 9.1 & 0.3 & 1.1 \\
\hline
\end{tabular}
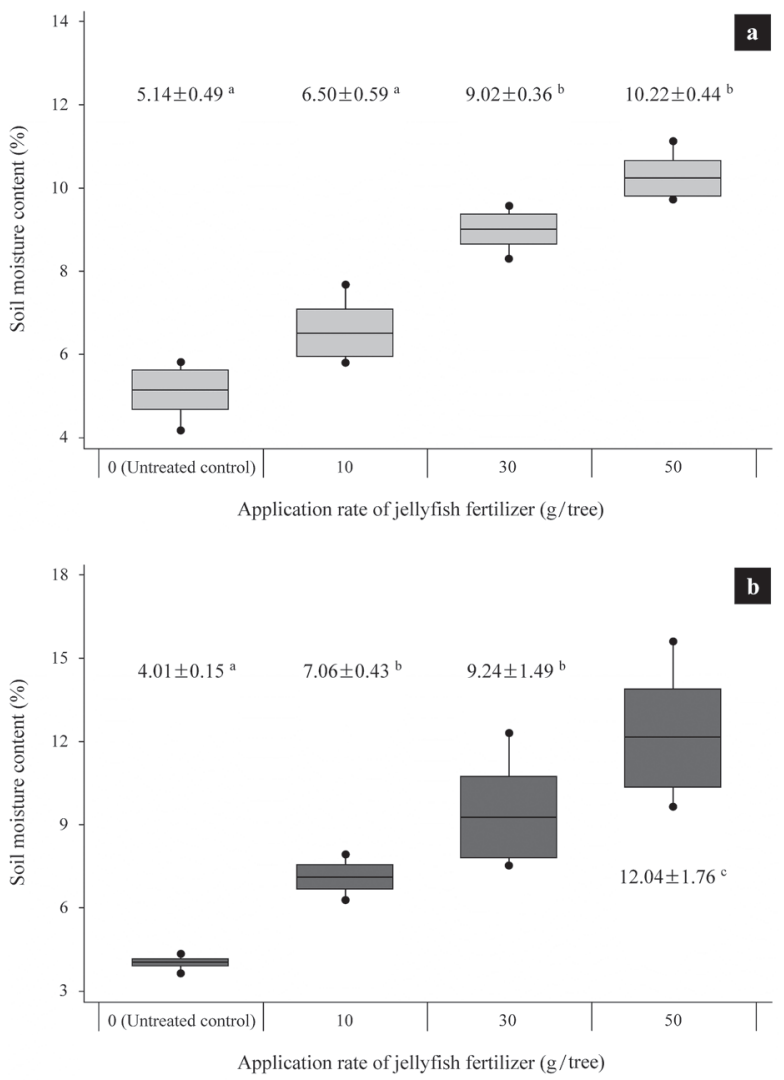

Fig. 2. Changes in soil moisture contents of subplots planted with (a) Pinus thunbergii and (b) Quercus palustris seedlings in relation to the application rates of jellyfish fertilizer. The line within box is the mean value, box ends are the mean \pm standard errors, and whisker dots are the maximum and minimum values. Different letter above the box indicates significant $(P<0.05)$ differences based on Tukey-HSD multiple comparisons. Values above the box-and-whisker plots represent the mean \pm standard errors.

cation of jellyfish fertilizer resulted in the highest available soil nutrients, which may be able to promote the growth of seedlings. The $\mathrm{OM}, \mathrm{NO}_{3}^{-}, \mathrm{P}_{2} \mathrm{O}_{5}$ and $\mathrm{K}_{2} \mathrm{O}$ contents in the subplot treated with the jellyfish fertilizer of $50 \mathrm{~g} /$ tree increased up to 1.3, 2.0, 2.0, and 1.5 times, respectively, compared to those in the untreated control subplot. Similarly, in this subplot, $\mathrm{Cl}^{-}$and $\mathrm{Na}^{+}$ contents increased up to 6.0 and 2.2 times, compared to those in the untreated control subplot.
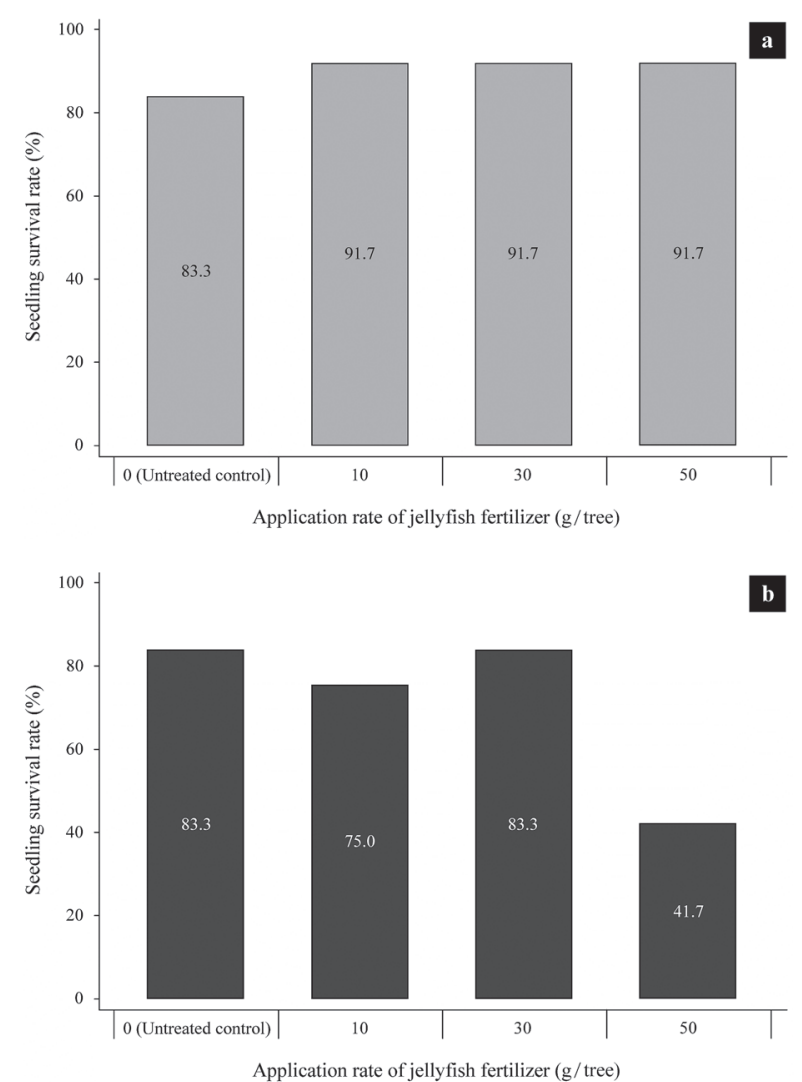

Fig. 3. Changes in survival rates of (a) Pinus thunbergii and (b) Quercus palustris seedlings in relation to the application rates of jellyfish fertilizer.

\section{Seedling survival rate}

The results showed that the survival rates of $P$. thunbergii and Q. palustris seedlings were differently influenced by the application rates of jellyfish fertilizer (Fig. 3). The survival rate of $P$. thunbergii seedling was weakly influenced by the application rate of jellyfish fertilizer. Compared to $P$. thunbergii seedling, $Q$. palustris seedling showed a less tolerance to the high application rate of jellyfish fertilizer. Specially, the seedling survival rate in the subplot treated with jellyfish fertilizer of $50 \mathrm{~g} /$ tree was only $41.7 \%$.

\section{Seedling growth}

Application of jellyfish enhanced the height growths of $P$. thunbergii and Q. palustris seedlings (Fig. 4). The mean height growth of both seedlings increased 

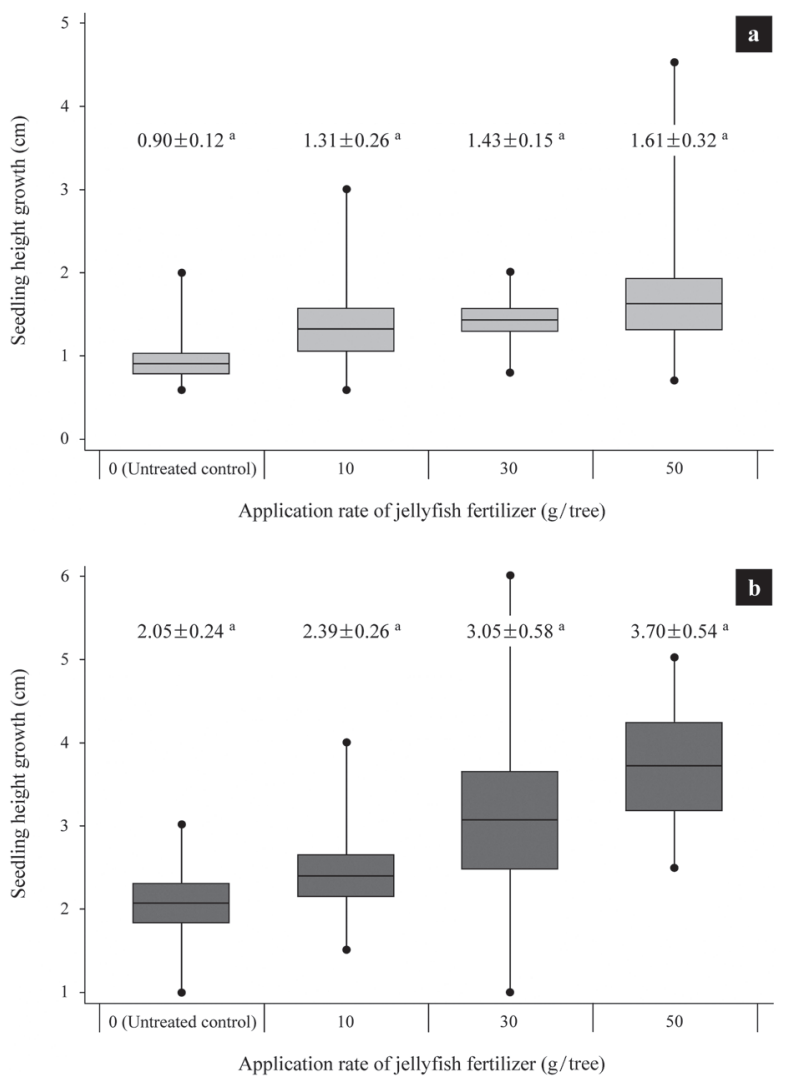

Fig. 4. Changes in height growths of (a) Pinus thunbergii and (b) Quercus palustris seedlings in relation to the application rates of jellyfish fertilizer. The line within box is the mean value, box ends are the mean \pm standard errors, and whisker dots are the maximum and minimum values. Different letter above the box indicates significant $(P<0.05)$ differences based on Tukey-HSD multiple comparisons. Values above the box-and-whisker plots represent the mean \pm standard errors.

slightly with increasing the application rate of jellyfish fertilizer. Although the mean height growth of $Q$. palustris showed relatively clearer increase compared to $P$. thunbergii seedling, there were no significant differences in both seedlings.

Whereas the root-collar diameter growth of $P$. thunbergii seedling was slightly variable along the spectrum of applied jellyfish fertilizer amount, the root-collar diameter growth of $Q$. palustris seedling increased with its application rate (Fig. 5). For the P. thunbergii seedling, the mean root-collar diameter growths were approximately 0.75 and $0.92 \mathrm{~mm}$ in the subplot untreated $(0 \mathrm{~g} /$ tree $)$ and treated with jellyfish fertilizer of $10 \mathrm{~g} /$ tree, respectively. However, the mean value $(0.86 \mathrm{~mm})$ in the subplot treated with jellyfish fertilizer of $30 \mathrm{~g} /$ tree was relatively lower than it in the subplot treated with jellyfish fertilizer of $10 \mathrm{~g} /$ tree. Unlike the $P$. thunbergii seedling, the root-collar diameter growth of $Q$. palustris seedling was positively related with the application rate of jellyfish fertilizer.

\section{Seedling quality index (SQI)}

The SQIs of both seedlings were positively influ-
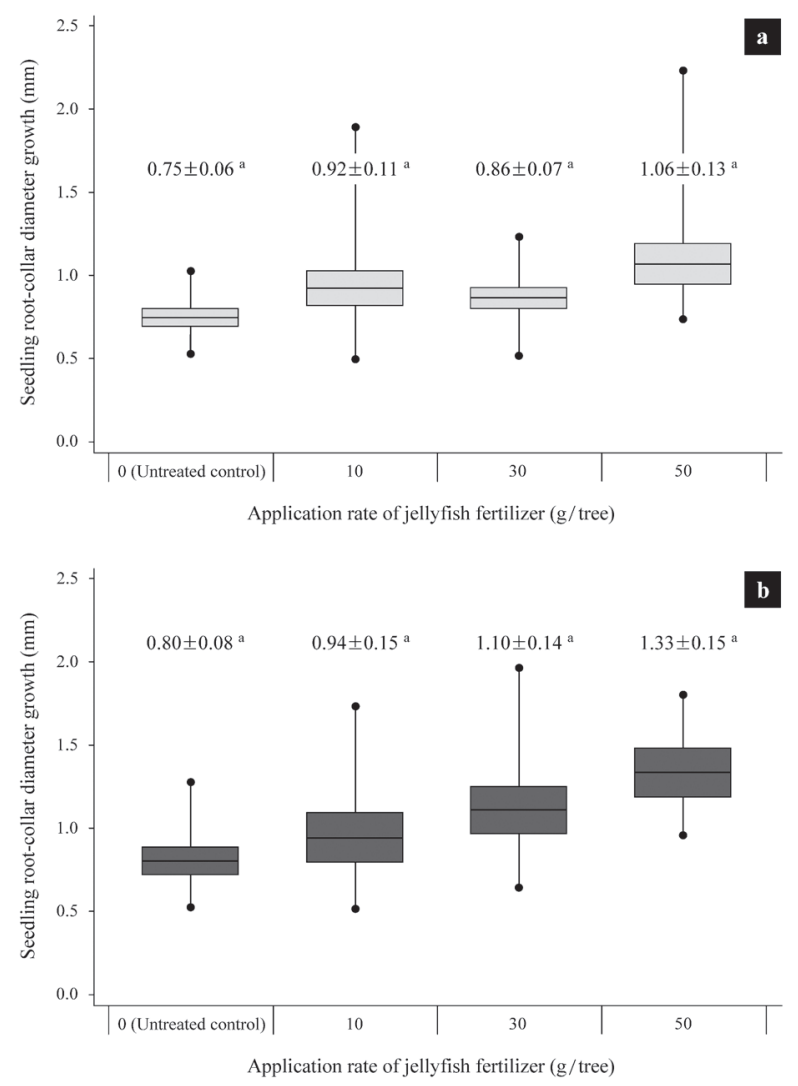

Fig. 5. Changes in root-collar diameter growths of (a) Pinus thunbergii and (b) Quercus palustris seedlings in relation to the application rates of jellyfish fertilizer. The line within box is the mean value, box ends are the mean \pm standard errors, and whisker dots are the maximum and minimum values. Different letter above the box indicates significant $(P<0.05)$ differences based on TukeyHSD multiple comparisons. Values above the box-andwhisker plots represent the mean \pm standard errors.

enced by the application rates of jellyfish fertilizer (Fig. 6). However, the SQI of $P$. thunbergii seedling showed considerably small values (approximately 0.30-0.65) compared to Q. palustris seedling (approximately 3.96.2 ), regardless of the application rate of jellyfish fertilizer. Specially, the SQI of $P$. thunbergii seedling in the untreated control subplot showed a larger range compared to other subplots, as well as non-significant differences among the treatments. Conversely, the SQI of $Q$. palustris seedling showed a clear increasing trend with the application rates of jellyfish fertilizer and partially significant differences among the untreated and treated subplots.

\section{DISCUSSION}

\section{Improvements of on-site soil conditions}

In this study, jellyfish fertilizer seemed to contribute high concentrations of the available moisture to soil conditions (Fig. 2). Similar to the present study, previous studies showed that the jellyfish fertilizer absorbed water seven to eight times greater than its own weight (Ezaki et al., 2008). Jellyfish fertilizer consists of high 

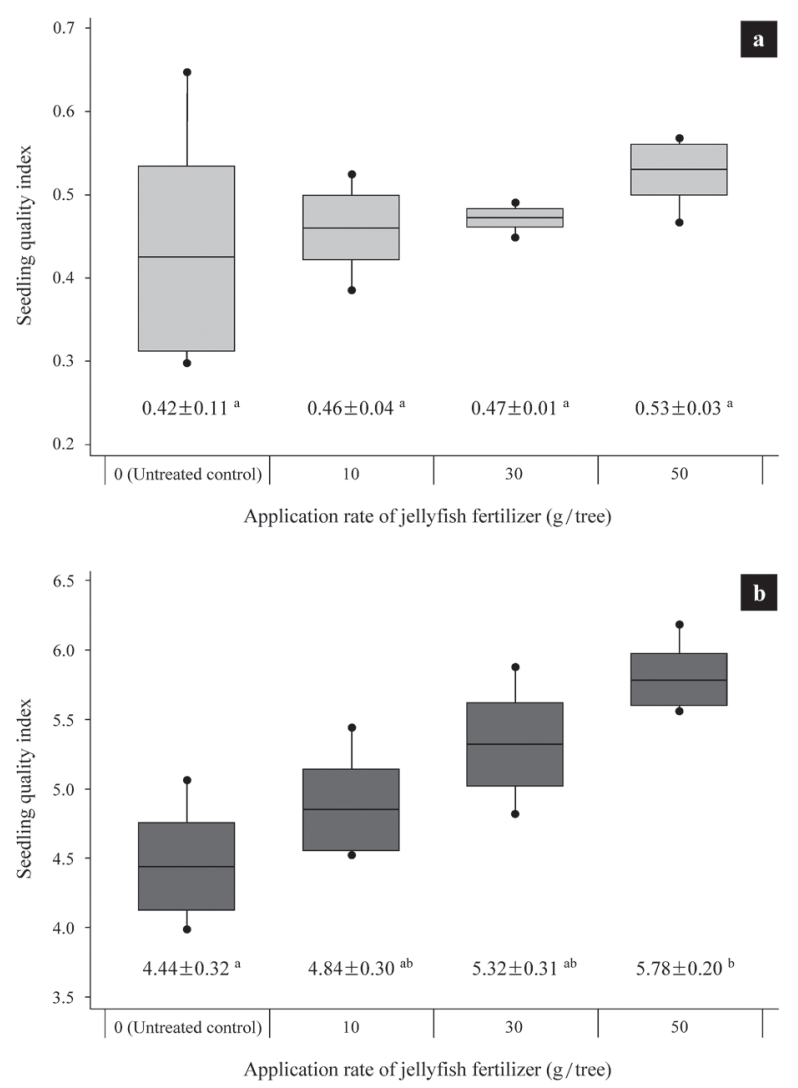

Fig. 6. Changes in seedling quality indexes of (a) Pinus thunbergii and (b) Quercus palustris in relation to the application rates of jellyfish fertilizer. The line within box is the mean value, box ends are the mean \pm standard errors, and whisker dots are the maximum and minimum values. Different letter above the box indicates significant $(P<0.05)$ differences based on Tukey-HSD multiple comparisons. Values below the box-and-whisker plots represent the mean \pm standard errors.

organic matter (approximately 81\%), which plays an important role for improving the physical structure of the soil; and consequently, increases the soil moisture. When jellyfish is distributed over the soil surface, it creates a vapor barrier between the soil and the atmosphere, resulting in decreases in soil temperature and evaporative water loss (Power, 2002).

The results in this study showed that the application of jellyfish fertilizer resulted in elevated concentration of the available nutrients (Table 2). Organic matter supplied by jellyfish fertilizer is also a suitable source for nutrient supply (Ezaki et al., 2008). In general, vegetation residues, manures, turfs and leaf falls on forest floor, and compost from organic wastes have been used to increase soil organic matter content and accordingly improve soil physical properties in croplands (Stratton et al., 1995). Improvement in soil aggregation by addition of organic matter positively affects the germination of seeds, and the growth and development of shoots and roots (Noordwijk et al., 1993). The reduction of soil pH could be caused by the presence of organic matter; that is, its decomposition and the release of organic acids into the soil played an important role for soil $\mathrm{pH}$ reduc- tion. Therefore, it is worthy to mention that jellyfish fertilizer has an acidic physiological effect. Application of organic fertilizers significantly increased levels of organic $\mathrm{C}$ and $\mathrm{N}$ and the formation of water stable aggregates, as compared with application of chemical fertilizers (Taiz and Zeiger, 2002; Chen et al., 2008). Therefore, it is recommended to apply liming materials in combination with jellyfish fertilizer to overcome the acid physiological effect of jellyfish fertilizer.

\section{Seedling survival and growths}

The overall survival rate of $P$. thunbergii seedlings was higher than the one of Q. palustris seedlings (Fig. 3). Particularly, in the subplot treated with jellyfish fertilizer of $50 \mathrm{~g} /$ tree, the survival rate of $Q$. palustris seedlings was less than $50 \%$ whereas the one of $P$. thunbergii seedlings was greater than $90 \%$. This should be because that the influence of jellyfish fertilizer on survival of the planted seedlings depends on salt resistance. Logan (1975) considered that thickness of $P$. thunbergii needles was responsible for its greater tolerance to salt. Therefore, thickness of $P$. thunbergii needles should help exclude salt ion and lead to higher survival rate than Q. palustris seedlings. However, salt toxicity is one of the major edaphic factors limiting vegetation production and eco-environmental quality in salinized and sodic soils (Barrick et al., 1987), especially for Q. palustris seedlings. Several studies (e.g., Ayers and Hayward, 1948; Garg and Gupta, 1997) reported the retardation of seedling settlement at high salinity. As a consequence, excessive salt concentrations, which can be caused by high application of jellyfish fertilizer, affect adversely the growing plants and/or root distribution (Miller and Donahue, 1990; Ramoliya and Pandey, 2006), although natural conditions and buffering capacity of the natural soil may slightly recovered the negative impacts of the elevated applications of jellyfish fertilizer (Hund, 2010).

Under the considering survival rates of both seedlings, the results showed that the optimum application rates of jellyfish fertilizer, which were sufficient to enhance the seedling growths, were $50 \mathrm{~g} /$ tree in the plot planted with $P$. thunbergii seedlings and $30 \mathrm{~g} /$ tree in the plot planted with $Q$. palustris seedlings, respectively (Figs. 4 and 5). As described previously, contents of soil moisture and chemical properties were remarkably increased in the soil treated highly with jellyfish fertilizer, compared with those in the untreated control subplot (Fig. 2 and Table 2). Specially, increment in available nutrients, including nitrogen, phosphorus and potassium which are key components to support growth of seedlings, enhanced the nutrient uptake (Lim and Cousens, 1986; Marschner, 1995). The increments in soil moisture and chemical properties caused by application of jellyfish fertilizer are likely to play an important role not only for enhancing the seedling growth but also for wide distribution of root system. In general, the root system, that is largely influenced by soil physical features (Gebauer et al., 2011), show large variability, especially under natural environmental conditions. However, Fares 
et al. (2008) and Ferreras et al. (2006) documented that organic amendment may facilitate root penetration by improving porosity and stabilizing soil structure. Although we did not deal with net growth of root system in this study, the SQI, which is considering the balance of above- and underground biomasses, was highest in the subplot treated with high application rate of jellyfish fertilizer (Fig. 6). This result reflects that the jellyfish fertilizer promotes soil amendment, and has a positive contributor to the growths of both shoot and root parts, which is obviously required to secure competitiveness in an early growth stage.

\section{CONCLUSIONS}

We focused on determining the optimum application rates of jellyfish fertilizer as soil amendment for enhancing the survival and growth of $P$. thunbergii and $Q$. palustris seedlings. Although the treatment plots in this study were not replicated due to spatial, temporal, and economical restrictions, the results showed that, in recently burned forest areas, the application of jellyfish fertilizer improved the chemical soil characteristics and enhanced the subsequent survival and growth of $P$. thunbergii and $Q$. palustris seedlings. At the same time, the results showed that the effect of jellyfish fertilizer on survival of $Q$. palustris seedlings varied with its application rate whereas the one of $P$. thunbergii seedlings increased with application rate of jellyfish fertilizer. The study suggests that (i) the application of liming materials in combination with jellyfish fertilizer is recommended to overcome the acid physiological effect and (ii) the washing stage to make jellyfish fertilizer prior to its application to the burned areas is required to decrease the $\mathrm{Cl}^{-}$and $\mathrm{Na}^{+}$accumulation. These findings are likely to provide important information regarding the establishment of forest restoration strategies in recently burned areas where natural regeneration is very slow.

Nevertheless, several knowledge gaps remain in our understanding of the effectiveness of rehabilitation treatments using jellyfish fertilizer. For example, the short term experiment might be not sufficient for observing the complete role of jellyfish fertilizer on soil fertility improvement and seedling growth enhancement. Ezaki et al. (2008) suggested that the effect of rehabilitation treatment using jellyfish fertilizer is expected to continue for a long duration. Also, this study does not cover a range of various forest types (e.g., species, seral stage, growth rate, artificial versus natural and harvested versus non-harvested) and/or geological conditions in the source watersheds; that is, this study is based on the results monitored using $P$. thunbergii and $Q$. palustris seedlings within plots measuring $4 \mathrm{~m}$ in width and $12 \mathrm{~m}$ in length. The results obtained from the limited seedling species and plot size should greatly regulate absolute magnitude of vegetation cover increment and subsequent sediment yield reduction after burning. Hence, the effectiveness of post-fire rehabilitation treatment using jellyfish fertilizer examined in this study may not be applicable to watersheds with different natural conditions.

\section{ACKNOWLEDGEMENTS}

The authors would like to thank Du-Song Cha and Wan-Geun Park for their offering valuable suggestions and comments on early drafts of this manuscript. This research was supported by a National Research Foundation of Korea grant funded by the South Korean government (Project No. 2010-0022532). Funding was also supported in part by Chonnam National University (2012) in the Republic of Korea.

\section{REFERENCES}

Abe, K. and R. R. Ziemer 1991 Effect of tree roots on a shear zone: modeling reinforced shear stress. Can. J. For. Res., 21: 1012 1019

Agee, J. K. 1993 Fire Ecology of Pacific Northwest forests. Island Press, Washington D.C.

Austin, R. C. and R. F. Strand 1960 The use of slowly soluble fertilizers in forest planting in the Pacific Northwest. J. For., 58 618-627

Ayers, A. D. and H. E. Hayward 1948 A method for measuring effect of soil salinity on seed germination with several crop plants. Soil. Sci. Soc. Am. Pro., 13: 224-226

Barrick, W. E., J. A. Flore and H. Davidson 1987 Deicing salt spray injury in selected Pinus spp. J. Am. Soc. Hortic. Sci., 104 $617-622$

Bayala, J., M. Dianda, J. Wilson, S. Quedraogo and K. Sanon 2009 Predicting field performance of five irrigated tree species using seedling quality assessment in Burkina Faso, West Africa. New Forest, 38: 309-322

Benda, L., D. Miller, P. Bigelow and K. Andras 2003 Effects of post-wildfire erosion on channel environments, Boise River, Idaho. For. Ecol. Manag., 178:1 05-119

Cannon, S. H., E. R. Bigio and E. Mine 2001 A process for firerelated debris flow initiation, Cerro Grande Fire, New Mexico. Hydrol. Process., 15: 3011-3023

Carlson, W. C. and C. L. Preisig 1981 Effects of controlled-release fertilizers on the shoot and root development of douglas-fir seedlings. Can. J. For. Res., 11: 230-242

Chen, D., H. Suter, A. Islam, R. Edis and J. R. Freney 2008 Prospects of improving efficiency of fertilizer nitrogen in Australian agriculture: a review of enhanced efficiency fertilizers. Aust. J. Soil. Res., 46: 289-301

Chun, K. W., J. I. Seo, K. J. Yeom, D. S. Cha, K. N. Kim, S. Inoue and T. Ezaki 2003 Variations of suspended solid and sediment yield in forest fire area: effects of coverage and afforestation. J. Rainwater. Catchment. Syst., 9: 13-17

Deans, J. D., W. L. Mason, M. G. R. Cannell, A. L. Sharpe and L. J. Sheppard 1989 Growing regimes for bare-root stock of Sitka spruce, Douglas fir and Scots pine: 1. morphology at the end of the nursery phase. Forestry, 62: 53-60

DeBano, L. F. 1981 Water-repellent Soils: A State of the Art (Gen Tech Rep PSW-46). US Department of Agriculture Forest Service Pacific Southwest Forest and Range Experimental Station, Berkeley, CA

Ezaki, T., S. Kohno, T. Edashige, D. S. Cha and K. W. Chun 2008 
Development of the revegetation material which using dried jellyfish (Nemopilema nomurai) powder. J. Jpn. Soc. Reveg. Technol., 34: 195-198

Ezaki, T., S. Kohno, K. Tetsuro, K. W. Chun and E. Damdinsuren 2011 The effect of jellyfish fertilizer on tree growth in hillside erosion control works. J. Jpn. Soc. Reveg. Technol., 37: 151154

Fares, A., F. Abbas, A. Ahmad, J. L. Deenik and M. Safeeq 2008 Response of selected soil physical and hydrologic properties to manure amendment rates, levels, and types. Soil Sci., 173: 522-533

Ferreras, L., E. Gomez, S. Toresani, I. Firpo and R. Rotondo 2006 Effect of organic amendments on some physical, chemical and biological properties in a horticultural soil. Bioresource Technol., 97: 635-640

Fukushi, K., N. Ishio, J. Tsujimoto, K. Yokota, T. Hamatake, H. Sogabe, K. Toriya and T. Nimomiya 2004 Preliminary study on the potential usefulness of jellyfish fertilizer. J. Bull. Soc. Sea Water Sci., 2: 209-217

Garg, B. K. and I. C. Gupta 1997 Saline Wastelands Environment and Plant Growth. Scientific Publishers, Jodhpur, India

Gebauer, R., D. Volar and M. Martinkova 2011 Impact of soil pressure and compaction on tracheids in Norway spruce seedlings. New Forest, 41: 75-88

Gimeno-García, E., V. Andreu and J. L. Rubio 2007 Influence of vegetation recovery on water erosion at short and mediumterm after experimental fires in a Mediterranean shrubland. Catena, 69: 150-160

Graham, R. T. 2003 Hayman Fire Case Study (Gen Tech Rep RM-114). US Department of Agriculture Forest Service Rocky Mountain Research Station, Ogden, UT

Hamilton, E. L. and P. B. Rowe 1949 Rainfall Interception by Chaparral in California. US Department of Agriculture Forest Service Pacific Southwest Forest and Range Experiment Station, Berkeley, CA

Hund, A. 2010 Genetic variation in the gravitropic response of maize roots to low temperatures. Plant Root, 4: 22-30

Ishii, H. and F. Tanaka 2001 Food and feeding of Aurelia Aurita in Tokyo Bay with an analysis of stomach contents and a measurement of digestion times. Hydrobiologia, 451: 311-320

Kang, Y. S. and M. S. Park 2003 Occurrence and food ingestion of the moon jellyfish (Scyphomoa: Ulmariidai: Aurelia aurita) in the southern coast of Korea in summer. J. Korean Soc. Oceanogr., 8: 199-202

Kim, C. G., K. I. Shin, K. Y. Joo, K. S. Lee, S. S. Shin and Y. S. Choung 2008 Effects of soil conservation measures in a partially vegetated area after forest fires. Sci. Total Environ., 399: $158-164$

Lanini, J. S., E. A. Clark and D. P. Lettenmaier 2009 Effects of fire-precipitation timing and regime on post-fire sediment delivery in Pacific Northwest forests. Geophys. Res. Lett., $\mathbf{3 6}$ : L01402

Lee, C. W., C. Y. Lee, J. H. Kim, H. J. Youn and K. Choi 2004 Characteristics of soil erosion in forest fire area at Kosung, Kangwondo. J. Korean For. Soc., 93: 198-204 (in Korean with English abstract)

Lim, M. T. and J. E. Cousens 1986 The internal transfer of nutrients in Scot pine stand: I. Biomass components, current growth and their nutrient contents. Int. J. For. Res., 59: 1-16
Logan, E. T. 1975 Factors affecting salt tolerance Pinus strobes and Pinus thunbergii. MS thesis. Rutgers University. New Brunswick, NJ

Marschner. H. 1995 Mineral Nutrition of Higher Plants. $2^{\text {nd }}$ ed. Academic Press Inc., San Diego, CA.

Marques, M. A. and E. Mora 1992 The influence of aspect on runoff and soil loss in a Mediterranean burnt forest (Spain). Catena, 19:333-344

Martin, D. A. and J. A. Moody 2001 Comparison of soil infiltration rates in burned and unburned mountainous watersheds. Hydrol. Process., 15: 2893-2903

McNabb, D. H. and F. J. Swanson 1990 Effects of Fire on Soil Erosion. In "Natural and Prescribed Fire in Pacific Northwest Forest", ed. by J. D. Walstad, S. R. Radosevich and D. V. Sandberg, Oregon State University Press, Corvallis, OR, pp. 159-176

Meyer, G. A. and S. G. Wells 1997 Fire-related sedimentation events on alluvial fans, Yellowstone National Park, U.S.A. J. Sediment. Res., 67: 776-791

Miller, R. W. and R. L. Donahue 1990 Soils: An Introduction to Soils and Plant Growth. $6^{\text {th }}$ ed. Prentice Hall Inc., Englewood Cliffs, New Jersey, pp. 216-304

Noordwijk, V. M., D. Schhonderbeek and M. J. Kooistra 1993 Root-soil contact of field-grown winter wheat. Geoderma, 56: $277-286$

Power, R. T. 2002 Effects of soil disturbance on fundamental sustainable productivity of managed forests. In "Proceedings of the Symposium on the Kings River Sustainable Forest Ecosystem project; Progress and Current status (Gen Tech Rep PSW-193)", ed. by J. Verner, US Department of Agriculture Forest Service Pacific Southwest Forest and Range Experimental Station, Berkeley, CA, pp. 63-82

Ramoliya, P. J. and A. N. Pandey 2006 Effect of salinization of soil on emergence, growth and survival of Albizzia lebbek seedlings. Trop. Ecol., 47: 27-36

Robichaud, P. R., J. L. Beyers and D. G. Neary 2000 Evaluating the effectiveness of postfire rehabilitation treatments (Gen Tech Rep RMRS-63). US Department of Agriculture Forest Service Rocky Mountain Research Station, Fort Collins, CO

Rose, R. and J. S. Ketchum 2003 Interaction of initial seedling diameter, fertilization and weed control on Douglas-fir growth over the first four years after planting. Ann. For. Sci., 60 625-635

Seo, J. I. 2004 Effects of vegetation, burnt trees and mulching sheets on soil outflow in forest fire area. MS thesis. Kangwon National University, Chuncheon, Korea. (in Korean with English abstract)

Seo, J. I., K. W. Chun, S. W. Kim and M. S. Kim 2010 Rainfall pattern regulating surface erosion and its effect on variation in sediment yield in post-wildfire area. J. Korean For. Soc., 99: 534-545 (in Korean with English abstract)

Shakesby, R. A. and S. H. Doerr 2006 Wildfire as a hydrological and geomorphological agent. Earth-Sci. Rev., 74: 269-307

Stratton, M. L., A. V. Barker and J. E. Rechcigl 1995 Compost. In "Soil Amendments and Environmental Quality", ed. by J. E. Rechcigl, CRC Press, Boca Raton, FL, pp. 249-309

Swanson, F. J. 1981 Fire and geomorphic processes. In "Fire regimes and ecosystem properties (Gen Tech Rep WO-26)", ed. by H. A. Mooney, T. M. Bonnicksen, N. L. Christensen, J. E. Lotan and W. A. Reiners, US Department of Agriculture Forest 
Service, Washington DC, pp. 401-420

Taiz, L. and E. Zeiger 2002 Plant Physiology. $3^{\text {rd }}$ ed. Sinauer Associates Inc., Sunderland, MA

Uye, S. and H. Shimauchi 2005 Population biomass, feeding, respiration and growth rates, and carbon budget of the scyphomeuse Aurelia aurita in the Inland Sea of Japan. J. Plankton
Res., 27: 237-248

Watson, A., C. Phillips and M. Marden 1999 Root strength, growth, and rates of decay: root reinforcement changes of two tree species and their contribution to slope stability. Plant Soil, 217: 39-47 